\title{
Herder og Grundtvig - sonderinger
}

\author{
Af Johannes Adamsen
}

Til minde om forstander Jens Bonderup, Ry Højskole (1945-2000)

Lige så oplysende det er med Jakob Balling at se Grundtvig som den sidste gammeleuropæer, lige så vigtigt er det at fastholde ham som umiskendeligt moderne, dvs. præget på afgørende vis af oplysningstænkningens kritiske pointer. Det gammeleuropæiske er et begreb som Balling bruger for at belyse en dybtgående kontinuitet fra omkring år 800 til det 18. århundrede, og Jakob Balling udpeger store og fundamentale overensstemmelser i poesien hos så forskellige skikkelser som Dante, Milton og Grundtvig ${ }^{1}$. På den anden side må det stå klart, at Grundtvig tillige var så meget barn af tiden at ethvert argument for kristendommen og metafysiklignende sammenhænge skulle bæres af menneskesynet, dvs. Grundtvig argumenterede antropologisk og havde ikke længere ubrudt adgang til fx det kosmologiske eller ontologiske gudsbevis, eller - mindre filosofisk - til brug af undere og mirakler som bevisførelse ${ }^{2}$.

At Grundtvig netop både viderefører gamle, ja klassiske, tanker og synsmåder og alligevel er moderne, er i sig selv en væsentlig dimension til forklaring af stridsmål i forskningen, hvor gamle fænomener tager sig nye ud, eller omvendt reelt nye figurer fremstår med historisk selvfølgelighed.

På den baggrund kan man med fordel ty til genetiske undersøgelser til afklaring og bedømmelse af, hvorvidt fænomener hos Grundtvig er gamle eller nye, men akkurat de selvsamme undersøgelser vanskeliggøres, hvis man ikke nøje agter på konteksten. Og denne kontekst kan kun ret forstås, hvis man tør væbne sig med en præcis definition af pågældende undersøgelsesobjekt.

Mit ærinde er således at undersøge nogle områder hos Grundtvig ved at se dem i forhold til Herder. Men hvis en sådan sammenligning skal lykkes, er det altafgørende at bevidstgøre sig og udarbejde det dybtgående omsving som ligger imellem netop Herder og Grundtvig, et omsving som ikke bare præger stort set samtlige fænomener og enhver tænkelig anskuelse, men som er ganske vanskeligt at håndtere, da det stadig er en del af vores selvfølgelige forudsætninger. Derfor lader det sig alt for let overse og ikke sjældent tilbageprojicere på tiden forud. Dette omsving er selvfølgelig romantikken. 
Der kan ikke i det følgende på nogen måde være tale om fuldstændighed (det ville kræve en monografi), men kun om nogle sonderinger. Hensigten er faktisk ikke at påvise en større eller mindre afhængighed af Herder, men via en undersøgelse af de udvalgte motivers overensstemmelser eller forskelligheder at profilere forståelsen af Grundtvig. Efter en præsentation af Herder vil jeg kaste et blik på den mageløse opdagelse med den hensigt at vise Grundtvigs tidsbundethed. Dernæst undersøges historiesynet, for i forlængelse af de problemer som dér rejses at forsøge en bestemmelse af romantikkens indflydelse og Grundtvigs bibelsyn. Herefter vil jeg skitsere, hvordan den fornuftskritik og negligering af filosofien, som romantikken muliggør, udmønter sig i tab i såvel historieopfattelse som teologisk potentiale. Og endelig vil jeg kort præcisere hvordan den romantiske prægning kan forstås i relation til Grundtvigs umiskendelige oplysningsprojekt.

\section{Johann Gottfried Herder}

Enhver med selv et begrænset kendskab til Grundtvig-litteraturen er klar over Herders tilstedeværelse i baggrunden. Ganske vist kunne C.I. Scharling skrive sin Grundtvig og Romantiken uden at nævne ham, men han dukker uvægerligt op hvis man skriver om folk/folkelighed/nation/ nationalisme eller om historiesynet hos Grundtvig ${ }^{3}$. Alligevel en kort præsentation:

Johann Gottfried Herder blev født i 1744 i Mohrungen i daværende Østpreussen og studerede bl.a. under Kant i Königsberg (1762-64), inden han efter forskellige kirkelige stillinger, på foranledning af Goethe, tilbragte den sidste halvdel af sit liv som "Generalsuperintendent « (ca. biskop) i Goethes Weimar (1776-1803). Herder dør da Grundtvig er 20, altså efter romantikkens frembrud; også i Danmark hvor Steffens havde holdt sine epokegørende forelæsninger og Oehlenschläger havde skrevet "Guldhornene«.

Skønt næppe polyhistor af Leibniz' kaliber - det lod sig vist ikke mere gøre efter eksplosionen i fysiske og matematiske erkendelser (Newton, Leibniz selv, Euler m.fl.) - var Herder nærmest polyhistorisk belæst og skrev tillige om mangfoldige emner, hvad der alt i alt ikke gør ham let at præsentere. I discipliner som historiefilosofi, æstetik, sprogfilosofi, metafysik og teologi med GT, NT, dogmatik og homiletik, har Herder været og alle steder ydet væsentlige bidrag; det gør det vanske- 
ligt at overse ham. Ikke desto mindre var hans indvirkning på sam- og eftertid så gennemgribende at man end ikke citerede ham, som om man forudsatte alment kendskab til hans forfatterskab. Til trods herfor fik han meget hurtigt en position som »overhalet «, idet ikke mindst de unge romantikere så ned på ham; en overlegenhedsfølelse som vel dels var begrundet $i$ hans stilling som kirkens mand, dels i hans sene opgør med Kant $^{4}$.

Mest kendt af Herders mange værker er sikkert det som ikke med urette kaldes hovedværket, nemlig Ideen zur Philosophie der Geschichte der Menschheit, som udkom i fire bind fra 1784 til 1791, og som forblev uafsluttet. Nok lige så eller mere kendt er den lille og temmelig anderledes forløber Auch eine Philosophie der Geschichte zur Bildung der Menschheit fra 1774; også velkendt er den lille og til dansk oversatte Vom Erkennen und Empfinden der menschlichen Seele fra $1778^{5}$. I nyere tid har det lille skrift Über den Ursprung der Sprache (1772) ikke mindst inden for sprogfilosofien nydt stor bevågenhed. Men reelt er der nok mere tale om mindst fire hovedværker i Herders forfatterskab, nemlig ud over allerede nævnte Ideen, den tidligere Älteste Urkunde des Menschengeschlechts (1774-76) og de senere samlinger Briefe zu Beförderung der Humanität (1793-97) og Christliche Schriften (1794-98) ${ }^{6}$.

Som nævnt er Herders virkningshistorie mærkværdig; beundret og omstridt allerede i en ung alder, oplevede han at blive nærmest overhalet indenom medens han endnu var flittigt skrivende. Medvirkende hertil var det kulturelle klima i forlængelse af den franske revolution og den intellektuelle debat under den (fra senfirserne) voldsomme indflydelse fra Kant, og den tyske idealisme såvel som den gryende romantik. Dertil kom at den opsigtsvækkende "Atheismus-Streit" (hvor filosoffen Johann Gottlob Fichte i 1799 blev afskediget fra universitetet i Jena efter beskyldninger for ateisme) inddrog Herder, og han blev smædet og bagtalt af Fichte-tilhængere som hævdede at han selv trods sit embede som generalsuperintendent forfægtede slet dulgte ateistiske standpunkter. Alt dette hindrer dog ikke danske læsere, bl.a. den historisk og teologisk optagne Grundtvig, i ganske enkelt at læse hans skrifter.

\section{Hvor mageløs en opdagelse?}

Inden jeg direkte undersøger nogle emner i belysningen fra Herder, vil jeg vise hvor meget Grundtvig var indspundet i sin tids debat, nemlig i 
forhold til den mageløse opdagelse som den fremsættes i prøvende form i Kirkens Gienmoele fra 1825. Opdagelsen, som Grundtvig kaldte den, bestod i at gå historisk bag om Bibelen til den apostolske trosbekendelse, og herudfra påpege en levende, kristelig kirke, som var og er virkeligt og synligt til stede, som er »kiendelig ei blot for sine Fiender, men iscer for sine Venner «" . Baggrunden herfor var dobbelt. For det første havde Grundtvig i perioden fra sin »omvendelse«/krise i 1810 til 1825 på en gang forudsat Bibelens autoritet og samtidig romantisk arbejdet intensivt med historien som erkendelsesform; forholdet mellem disse var fortfarende et problem. For det andet var Grundtvig selvsagt på det rene med at tidens bibelvidenskab havde rejst uomgængelige spørgsmål og problemer, som bestred skriftsprincippet; og Kirkens Gienmoele blev derfor en mulighed for at afklare spørgsmålet, da prof. H.N. Clausen i 1825 udgav sit store værk Catholicismens og Protestantismens Kirkeforfatning, Lare og Ritus. Grundtvig mente at netop Clausen illustrerede selvmodsigelsen i på én gang at ville udøve skriftkritik og samtidig basere den protestantiske kirke på sola scriptura.

Og på det punkt havde Grundtvig for så vidt ret: Sola scriptura-argumentet bliver nemlig tydeligt i sin sårbarhed, når det - som hos Clausen - sammenstilles med den katolske kirkes dobbelte autoritetsprincip, både Bibel og kirke. Og allerede Lessing havde peget på at dette princip i den protestantiske udformning var uholdbart, netop fordi man fra reformationens begyndelse havde vidst at skriften var afhængig af kirken, var blevet til og kanoniseret under kirkens vejledning, altså helt igennem menneskelig ${ }^{8}$. Og Lessing pegede derfor på at før skriften var der en trosregel, regula fidei, der som lære dels regulerede troen, dels vejledte skriftforståelsen og - senere - skriftudvælgelsen, dvs. Bibelens samling og kanonisering. Lessing havde med andre ord indset at det problem, Grundtvig gør gældende mod Clausen, var højst reelt.

$\mathrm{Nu}$ har allerede Hans Martensen redegjort for at Grundtvigs opdagelse næppe er så mageløs, nemlig ved at henvise til Lessing ${ }^{9}$. Men i virkeligheden var problemet allestedsnærværende, og Grundtvigs løsning ligeså ${ }^{10}$. Herder skriver i forlængelse af Lessing også om »regula fidei ${ }^{11}$. Et andet eksempel som peger i retning af Grundtvig er Wittenbergerprofessor og Dresdener Oberhofprediger Franz Volkmar Reinhard (1753-1812), som Grundtvig ikke bare kendte til, men hvis død påvirkede Grundtvig til en prædiken med foransat mindedigt. Mig bekendt har ingen undersøgt Reinhards betydning for Grundtvig ${ }^{12}$, men flere ting gør sig gældende der peger på nødvendigheden af en afklaring. Jeg skal 
kun kort antyde hvorfor Reinhards indflydelse er en oplagt mulighed: Reinhard hører til den såkaldt sachsiske supranaturalisme. Supranaturalismen tilsluttede sig for så vidt oplysningstidens fornuftideal og lod det føre sig til Bibelen, fordi man nemlig i - tvivlsom - forlængelse af Kant lod fornuftens grænse være åbenbaringen. Dvs. at man ikke antastede fornuften, men ved hjælp af fornuften kom til Skriften. Reinhard satte ikke kun Skriften ind som vejledning hvor fornuften bedømtes som utilstrækkelig, men han lod Luther og de reformatoriske bekendelsesskrifter være støtter, sådan at Bibelen først i forlængelse af disse lod sig åbne på ægte vis ${ }^{13}$. Det vil sige at Reinhard som oplysningsteologerne, neologerne, udlagde Bibelen sædeligt-religiøst, og bekendelsesskrifterne hjalp ham til ikke at betragte Bibelen som lovbog, men som en venlig hjælper. Således kunne han på en gang være oplysningsmand og luthersk-kristen ${ }^{14}$.

Når Grundtvig mindes Reinhard er det netop som den der stod vagt ved Luthers grav mod rationalisterne, og Reinhard er således som Johann Georg Hamann (1730-88) bevidst lutheraner i en tid hvor det lutherske i øvrigt ikke agtedes, og lang tid før en egentlig Luther-forskning kom i gang.

Min hensigt med at omtale Reinhard er tofoldig. For det første, trods de hårde kommentarer i Verdens-Krøniken af 1817, må Grundtvig have været meget optaget af ham, hvad mindedigtet noksom viser. Derfor kan der i beskæftigelsen med Reinhard have været en impuls til den kirkelige anskuelse; idet den danske kirke ikke anerkendte Konkordiebogen som forpligtende lære kan Grundtvig have tænkt i tilknytning til Reinhard (og sandsynligvis fra 1823: Irenæus) men uden Konkordiebogen; altså de fælleskirkelige bekendelser og Den Augsburgske Konfession. En sådan påvirkning kan ses i Om den sande Christendom fra 1826. Hvor Grundtvig i Kirkens Gienmoele dristigt hævder den apostolske trosbekendelse som eneste norm, trækker han sig året efter i just nævnte skrift tilbage i noget der ligner en Reinhardsk position, minus Konkordiebogen, for senere at genoptage den i sandhed mageløse tilbageføring af den apostolske trosbekendelse til Kristus selv ${ }^{15}$. - Det viser at ideen med at søge til bekendelsesskrifterne før Bibelen, under bevarelse af $\mathrm{Bi}$ belens autoritet, simpelt hen var oppe i tiden, og altså ikke spor mage$1 ø s t^{16}$.

For det andet kunne man i forlængelse af Reinhard og supranaturalismen placere Grundtvig mere præcist i en kirkehistorisk sammenhæng, hvor hans lutherske biblicisme i årene fra 1810 til 1825 forstås 
uden skældsordslignende og vildledende karakteristika som eksempelvis »bodskristendom «, »ortodoksiens gnosticisme« og "pilgrimskristendom $\ll^{17}$. Tværtimod, netop at tage både oplysningstidens fornuft og den kirkehistoriske arv med Bibel, Luther og trosbekendelser alvorligt var andet og mere end en gentagelse af gamle positioner, men et forsøg på at tage tidens udfordringer op under bibeholdelse af traditionens tyngde. Det moderne og i denne her sammenhæng væsentligste er at supranaturalismen ikke udelukker fornuftig beskæftigelse med historien, dvs. en beskæftigelse med historien på moderne, videnskabelige præmisser. I det lys bliver Grundtvigs bibelske kristendom og hans samtidige historiebeskæftigelse knap så egensindig.

I den sammenhæng kan man også pege på en vigtig skikkelse som den reformerte Bremerpastor Gottfried Menken (1768-1831), der ikke bare ud fra en biblicistisk ortodoksi forkastede den traditionelle forsoningslære med den begrundelse at Gud helt igennem er kærlighed, den såkaldte kærlighedsmonisme. Men tilmed skrev han fra samme biblicistisk frelseshistoriske grundsyn historie, hvor tolkningsmønstret blev hentet fra Danielsbogen kap. 2; således er vi nu i det sidste, jernets, verdensalder så enhver forestilling om den franske revolution som noget nyt og bedre er forkastet. Menken havde en stor indflydelse i Tyskland ${ }^{18}$.

Alt dette betyder i sin tur ikke at Grundtvigs historiesyn var foranlediget af, endsige præget af supranaturalismen, kun at den var muliggjort heraf (så meget desto vigtigere at fastslå, da hele sammenhængen med Reinhard og Menken foreløbig svæver i luften uden nærmere påvisning). Men var historiesynet herdersk?

\section{Historien}

Som nævnt er det akkurat i forhold til historieopfattelsen at Grundtvigs forhold til Herder oftest påkalder sig opmærksomhed. Og angående det genetiske kan jeg da også henvise til Michelsen og Vind ${ }^{19}$. Hvad der her skal nævnes er deres respektive historiesyns programmatiske karakter; og tillige hvorfor Grundtvigs historieskrivning i en afgørende betydning forbliver uhistorisk.

Herders problem med historien havde sin grund i oplysningstidens naturvidenskabeligt inspirerede fornuftssyn. Heri var impliceret et opgør med den aristoteliske kosmosopfattelse, hvori alt, ethvert væsen og enhver ting, havde sit formål (telos) i sig. Den moderne naturvidenskab 
(Galilei og Newton og deres ligesindede) reducerede den aristoteliske årsagslære til kun én, nemlig det vi i dag forstår som årsag, kausalitet. Altså stod man med et begreb om fornuft som dels tænkte årsag-virkning, dels tænkte induktivt, almengældende, og fremskridtsrettet. I det øjeblik man forsøgte at tænke historien på disse præmisser, måtte den med nødvendighed enten fradømmes rationalitet eller indordnes $i$ et forløb i retning af større rationalitet, dvs. akkumulerende som naturvidenskaben, og det vil også sige, som en befrielse fra overtro og fordomme. Den endimensionalitet, som historien således blev underlagt, implicerede nødvendigvis en spaltning i dem, de overtroiske og ufornuftige, hyllet i fordomme og uvidenhed, og os, de fornuftige, subsidiært dem på vej mod fornuft og videnskabelighed.

Det positive heri var, og det bør man holde sig klart, at man gjorde frihedssynet gældende som universel målestok. Det negative var, at alle tidligere folk kun havde mening som bærer af en proces, instrumentelt, men de havde ingen mening i sig selv, indlejrede i fejlagtige fordomme som de var. Herders grundtanke er det både at fastholde et udviklingssyn, men nu forstået under forsynets ledelse, og samtidig at forstå historien i sin engangskarakter, sådan at ethvert folk, enhver periode tillige har en mening i sig selv. Det, som altså for den rationalistiske fornufts domstol tager sig ud som overtro og fordomme, er måske nok fordomme, men disse er, hævder Herder veloplagt i 1774, et sundhedstegn ${ }^{20}$. Selv om Herder ikke gentager denne provokerende pointe i Ideen, bibeholder han såvel forsynstanken som dobbeltheden af enhver periodes egenret og udvikling.

Grundtvig behøver på sin side for så vidt ikke begrunde sin historieskrivning, det har Herder jo gjort. I Danne-Virke skal historien erstatte enhver filosofi, den er uomgængelig og modsat systemet. Det hedder i stykket »Om det Philosophiske Aarhundrede«:

Holde vi nu fast ved den klare Sandhed at det er det timelige Menneske vor Fornuft kan og skal begribe, da indsee vi let at al sand Vidskab maae i alle Maader være historisk, historisk fordi Fornuften finder intet i sig selv uden Maalestokken for timelig Sandhed, og maae udenfor sig søge Vidskabens Indhold, historisk, fordi Mennesket udvikler sig i Tiden og kan kun begribes i den, historisk, fordi den maae være stykkeviis og kan kun sluttes med Tiden. Heraf følger først at enhver Vidskabs-Lære som ei forklarer Krøniken er falsk, og dernæst at enhver saadan der udgiver sig for at være færdig, 
ethvert philosophisk System er som Heelt en stor Løgn, hvormegen Sandhed det end i det Enkelte kan have, thi er det Mennesket som skal begribes, udvikler Mennesket sig i Tiden, og er Fornuften Udtrykket for det sig giennem Tiden udviklende menneskelige Begreb, da kan vi jo under Tidens Løb ei have noget sandt Begreb om Menneske eller menneskelig Vidskab uden som om noget der er i Begreb med at udvikle sig, og ei i Sandhed begribe mere end hvad der alt er udviklet, eftersom Begrebet just er det eneste som udvikler sig. ${ }^{21}$

Når dette stykke kan præsentere sig anti-filosofisk beror det på et øjenbedrag. Strengt taget er det ikke anti-filosofisk, for Vidskab er nemlig et dansk, grundtvigsk ord for filosofi, men det er filosofi under antropologisk fortegn. Når naturen uden videre falder ud skyldes det ganske enkelt at Grundtvigs filosofiske antropologi, eller antropologiske filosofi, selv er filosofisk begrundet. Baggrunden er fornuftens egen historisering:

at Fornuften i Menneske-Slægten ligesom i det enkelte Menneske er Begrebet og Udtrykket for den aandelige Vext og Udvikling, kan ikke nægtes, og man indseer da let, at baade kan den komme til at begribe hvad den før aldrig har begrebet, og den maae komme dertil, hvis dens Bane ei ubetimelig afskiæres. ${ }^{22}$

Men Grundtvig går et skridt videre end denne regulære historiefilosofi, for denne henter igen sin begrundelse fra filosofiske og teologisk antagelser. Det antages filosofisk at fornuften må kunne begribe sig selv og "Alt hvad der hører under dette Begreb, altsaa det hele timelige Menneske og alt det Timelige«; og denne historiske antropologi sigter på "uagtet det Timelige ingenlunde kan forklare det Evige - netop at bidrage til en forklaring af det evige i kraft af det timelige:

maatte dog det Timeliges Forklaring have den mest afgiørende Indflydelse paa Menneskets Vished om det Evige og bringe en middelbar, billedlig Erkiendelse tilveie, thi det Timelige kan jo i Sandheden kun være et Billede af det Evige, og naar man klarlig begriber et sandfærdigt Billede, da veed man jo hvad det betegner og betyder, uagtet man ikke begriber det Afbildede selv. ${ }^{23}$ 
Grundfiguren er i virkeligheden en klassisk analogitænkning, nemlig at en sand forståelse af det skabte oplyser om Skaberen ${ }^{24}$; men denne metafysiske struktur viser sig akkurat i sin processuelle, historiske opfattelse som et moderne svar på nye udfordringer. Alene forskydningen mod det historiske afslører det moderne. Tillige viser det sig andetsteds, idet det klassiske metafysiske spørgsmål om menneskets bestemmelse besvares så at sige selvreferentielt: Det drejer sig ikke om frelse, selvhengivelse i Gud, etiske krav eller lignende, det er menneskets bestemmelse at komme til selvforståelse:

At begribe sig selv i Sandheden det er da det store Maal for den menneskelige Fornuft, Høiden af menneskelig Vidskab, og det første Skridt dertil er Fornuftens aandelige Selv-Bevidsthed i Sandheden, Vedkiendelse af sig selv i sit sande Forhold til det Evige, til den guddommelige Fornuft og Sandhed. ${ }^{25}$

Denne hævdelse af forståelsens primat (i.e. »Fornuftens aandelige SelvBevidsthed i Sandhed«) er afgørende til nøjagtig erkendelse af Grundtvigs historiefilosofi. Men hos Grundtvig står historieforståelsen ikke alene under en antropologisk filosofis fortegn, også en genuin teologisk præmis hævdes: »... ikke heller vil jeg her bevise, hvad der imidlertid er vist, at ingen Fornuft bliver selvbevidst i Sandheden, dersom den ikke alt før var i Sandheden formedelst Troen ... $\ll^{26}$. Her anføres en slags credo ut intelligam, vel at mærke troen som forudscetning for enhver historiefilosofisk erkendelse. Selvforståelsen er en selvbevidsthed som kender sin begrænsning i forhold til og afhængighed af det evige, en selvbevidsthedsformel som går tilbage til det græske »kend dig selv«, dvs. "vid at du er dødelig «, i modsætning til de udødelige guder. Grundtvig begrunder dog denne selvbevidsthed i kristendommen.

Grundtvigs historiesyn har altså endnu på sæt og vis i Danne-Virkeperioden, 1816-19, erkendelseskarakter. Som ovenfor citeret har vidskaben karakter af erkendelse, der i kraft af troen giver en forståelse af det timelige mhp. erkendelse af det evige. I stykket »Om Mennesket i Verden « (Danne-Virke II, 1817) siger Grundtvig om poesien, at »den er i sin sande Skikkelse intet andet end den billedlige Beskuelse af Tingene i deres skabde, aandige Forhold, i deres Forhold til den skabende Sandhed.« (s. 162) På trods af at denne beskuelse »ligesom af sig selv«, som Grundtvig fortsætter, kan »avle Ordet og Sproget«, er poesien tænkt romantisk som en erkendelsesform, men en erkendelse som endnu ikke 
konsekvent, eller om man vil: systematisk, er blevet koblet sammen med et handlingsimperativ.

Springer man fra Danne-Virke til Haandbog $i$ Verdens-Historien (1833-56) ses en lignende forståelse, dog ikke om poesien: "... det er Verdens-Historiens Kald at oplyse den rette menneskelige Sammenhæng i Levnets-Løbet, og derved mægle Forlig mellem det Gamle og det $\mathrm{Ny} \ll^{27}$. Det ses klart at verdenshistorien iflg. Haandbogen, og poesien som den blev forståt i 1817, er to sider af samme sag, de skal begge fange den dybere - i.e. åndige - forståelse af det skabte, vel at mærke forstået historisk. Og dog: Lidt tidligere i Haandbogen kan Grundtvig skrive om den »historisk-poetiske Tilbage-Gang til Middel-Alderen, med virkelig Begeistring for den $\aleph^{28}$, hvormed der sigtes til at man må forstå historiens drivkraft, dens skabende moment; historisk-poetisk er faktisk en hermeneutisk kategori, for det er ikke nok at kende begivenhederne, men man skal forstå ånden bag disse. Derfor kan denne tolkningsform også binde historien sammen som på én gang erkendelse og handlingsincitament, idet den tilstrækkelige historisk-poetiske anskuelse i rette form forløser de vigtigste historiske begivenheder som udslag af ånd:

Ved at sammenligne Kors-Toget med Iliaden klarer det sig nemlig ret, at Grækerne kom for tidlig, thi deres Helte-Digt fattes aabenbar, hvad det dog ærlig fortjende: en tilsvarende »Universal-Historisk" Begivenhed, som »den Trojanske Krig«, der endog neppe kan kaldes »historisk, " jo ingenlunde er, medens Kors-Toget, der er en Universal-Historisk Begivenhed, ikke blot fattes et tilsvarende Helte-Digt, men savner hele det yndige, midt i Kampen rolige Anstrøg GrækerAanden gav Alt hvad den skabde. ${ }^{29}$

Tankegangen er tydeligt nok, at Iliaden er stor litteratur, men baggrunden kun lokal og i sig selv uden virkninger på den kommende historie; hvorimod korstogene har sand »universalhistorisk « betydning, men omvendt savner de en litteratur som kan forløse deres ånd - til forståelse og nybeånding. Det historisk-poetiske skal altså på én gang fange ånden bag de store begivenheder og i kraft heraf anspore til nye heltegerninger. På denne måden kan tolkningsformen både binde erkendelse og inspiration (i.e. "beåndelse«) sammen, og fastholde hele historien som en sammenhæng. Senere i værket lyder det med genanvendelse af Fugl Fønix-motivet sådan: 
Saaledes svarer i Nyaarstiden det Classiske »Skole-Støv« til Asken, hvoraf Phønix-Ormen udviklede sig, og jeg tvivler da ikke om, at vort »Bogorme-Væsen « jo paa sine Steder baade vil faae Vinger som en Ørne-Unge, og voxe til en Phønix den Anden, der kan bære sin Fader og fortsætte hans Levnets-Løb, hvad kun da skeer, naar Nyaarstidens Vidskab, udsprunget som Lys af Middelalderens Ild, forklarer Oldtidens Aand, ikke blot paa Papiret, men i Gierning og Sandhed. ${ }^{30}$

Dette centrale citat har næsten det grundtvigske historiesyn i koncentrat. Fønix-motivet ${ }^{31}$ viser med al ønskelig tydelighed at det ikke drejer sig om gold erkendelse, endsige indlæring, men om at den virkende ånd fra oldtiden i nutidens vidskab skal forklare sig, dvs. forklares, opklares, i "Gierning og Sandhed «; igen er erkendelse og handlingsincitament sammenbundet. Dybdestrukturen i Grundtvigs historiesyn er fuldstændig som hos Herder, at historien skal fortælles på en sådan måde at virkende årsager, i.e. ånd, igen skal gribe og inspirere til handling på en ny tids præmisser. Hvornår denne sammenkobling făr en vis indre konsekvens er jeg usikker på, for endnu i 1824 kan Grundtvig begrænse friheden til at udøve kristelige bedrifter ${ }^{32}$ - selv om omfanget af denne indskrænkning nok ikke skal tolkes for hårdhændet. Men meget taler for at sammenkoblingen hænger sammen med de mere omfattende ændringer i begyndelsen af 1830 'rne, eller måske allerede i 1824 eller $1825^{33}$.

Som hos Herder skrev jeg. Men enhver som har læst både Herder og Grundtvig vil have set de markante forskelle i historieopfattelsen. Den påpegede hermeneutiske dybdestruktur med dens samtidige interesse $\mathrm{i}$ tolkning og handlingsansporing findes i markant grad hos Herder, lige fra hans tidligste til de sene skrifter; det er bl.a. det han forstår med det flertydigt brugte begreb palingenesi, genfødsel, dvs. historiens genfødsel i nutiden. Som et enkelt eksempel henviser jeg til den lille afhandling "Über die menschliche Unsterblichkeit« fra $1791^{34}$.

De førnævnte divergenser mellem historiesynet hos Herder og Grundtvig skriver sig fra vidt forskellige udgangspunkter, som endda lader sig problemfrit oplede i deres respektive historiefremstillinger. Først og fremmest fastholder Grundtvig en slags biblicistisk skriftsyn, og desuden, og vel af samme grund, lykkedes det aldrig Grundtvig at forene de to menneskelige tolkningsformer han sloges med $i$ en lang periode fra $1810 \mathrm{og}$ fremefter; for spørgsmålet er om løsningen fra 1832 med Nordens Mythologi havde noget med den sag at skaffe. Var dette med 
megen ret berømmede frihedssyn ikke nok så meget et resultat af kirkespørgsmålet, som det er hævdet af Anders Pontoppidan Thyssen og Bent Christensen ${ }^{35}$, og ikke en løsning af fundamentale problemer om kristendommens sammenhæng med en moderne verden? Måske kan man med Herder som katalysator nærme sig problemet.

\section{Bibelsyn og romantik}

Det er let at koble Grundtvigs tanke om folket med Herders ditto. Men det rejser straks spørgsmålet om, hvorfor Grundtvig i sine verdenshistorier afgrænser sig fra alle de folk, som ikke er kommet i kontakt med kristendommen, en afgrænsning som bliver meget påfaldende sammenlignet med Herders skrifter. En anden slående forskel er Herders omfattende inddragelse af naturen, ja meget store dele af Ideens to første dele (af $i$ alt fire) fyldes af omfattende naturfilosofiske udredninger, lige fra jordens stilling i universet til menneskets stilling blandt dyrene.

Hos Herder begrundes begge dele, både den sande universelle fremstilling af alle jordens kendte egne og folk såvel som naturens inddragelse, med en omfattende filosofisk konception, nemlig i det man kunne kalde en dynamiseret, eller historiseret spinozisme. Spinozas enhedstænkning kom ind i den tyske debat i forlængelse af Lessings død i 1781, men det korte af det lange er at dens grundtanke om det ene og altet, hen kai pan, fortfarende var en filosofisk udfordring, ikke mindst for den tyske idealisme, særlig Schelling og Hegel. Det er endnu virkende klange fra den sang som høres i Oehlenschlägers »i Sole, i Violer«. Anderledes udtrykt: Det filosofiske problem, som rejses med Spinoza, ligner til forveksling den romantiske tanke om sammenhængen mellem ånd og natur. Udtrykket »til forveksling« er nu det som kalder på en præcisering, da det implicerer at romantikken nok ligger i forlængelse af Herders tænkning, men alligevel ikke er en direkte arvtager. Hvad er romantik da, og hvorfor er Herder ikke romantiker?

Spørgsmålet har relevans i Grundtvig-forskningen. På den ene side kan Scharling skrive en bog om Grundtvig og romantikken uden at definere sidstnævnte, og dertil kan han hævde, at Grundtvig overvandt romantikken allerede før 1810. Romantikken sætter Grundtvig i gang, men han bliver ikke romantiker. Samtidig kan, for at tage et eksempel, Henrik Wigh-Poulsen overbevisende vise at Grundtvig stadig og umiskendeligt $\mathrm{i}$ sine digte er romantisk ${ }^{36}$. En væsentlig indfaldsvinkel til 
afklaring kan naturligvis være Jørgen I. Jensens forslag om en samtidighed af tider, dvs. at Grundtvig i forskellige sammenhænge ikke nødvendigvis søger teoretisk enhed, således at en overvunden romantik i forhold til Schelling kan eksistere side om side med romantiske træk i Grundtvigs egen digtning ${ }^{37}$. Men problemet består alligevel, og forskellen mellem Herder og Grundtvig kan præciseres ved ret forståelse af romantikbegrebet.

Romantikken defineres ikke hos Scharling, sandsynligvis fordi han forudsætter den velbekendt. Men to indvendinger kan rejses herimod. For det første kan man skelne mellem to former for romantik, en filosofisk og en litterær, og for det andet kan man skelne mellem en tidlig og en sen, omslaget ligger omkring 1805-6. Således er der forskel på Tiecks og Wackenroders romantik knyttet til romangenren og Schlegels, Novalis’ og Schellings med afsæt $\mathrm{i}$ et forsøg på at overvinde, hvad de så som problemer i Kants filosofi, denne ofte forstået gennem Fichtes tolkning. Det er vigtigt at bemærke, at en definition må være heuristisk, subsidiært præskriptiv, og ikke kan påberåbe sig ren deskription. Og det er tillige vigtigt at undgå enhver nedladende sprogbrug, en som ofte har knyttet sig til både oplysnings- og romantikbegrebet.

Hvis oplysning med Dilthey kan bestemmes som bl.a. indeholdende fornuftens autonomi og fremskridtstro, så kan romantik forsøgsvis bestemmes som en korrektion af tanken om fornuftens autonomi, eller, filosofisk formuleret, et forsøg på at indplacere subjektsfilosofien i en større sammenhæng. Men denne bestemmelse er utilstrækkelig, for også Kant og Herder ville forstå subjekt og fornuft som i en vis, men afgørende, forstand som restringerede. Romantikken adskiller sig fra oplysningstænkning ved at fornuften ikke bare sættes i sammenhæng med instanser uden for fornuften, men fornuften ønskes forstået som andet og mere end (Kants kritiske) fornuft, nemlig - således romantikerne: den skal poetiseres. Hvis min operationelle definition har en rimelig gyldighed, dvs. at den på trods af dens heuristiske definition trods alt indfanger noget centralt i den faktiske romantik, så kan man også bestemme hvilken ændring romantikken selv undergår omkring 1805-6. For den dobbelthed de tidlige romantikere, særlig Schlegel, Schelling, Novalis og Hölderlin, tager udgangspunkt i, betyder at lige så vel som videnskaben skal poetiseres skal poesien videnskabeliggøres. Forandringen er at det sidste element, poesiens videnskabeliggørelse, taber betydning. Derfor bliver romantik efterhånden til et opgør med fornuften til fordel for anelse, drøm og sang (dvs. kunst), for nu at parafrasere Schack Staf- 
feldt i digtet »Indvielse«. Og i forlængelse af kunstens centrale betydning bliver kunstneren et særligt menneske, et geni. Det implicerer også omvendt, at et geni har kunstneriske træk uanset om det er en videnskabsmand, filosof eller noget tredje.

I disse bestemmelser ligger en i denne sammenhæng tilstrækkelig forståelse af romantikken som gør det muligt at forstå Grundtvig som romantiker, og Herder som (korrigerende) oplysningstænker. For det første ser man at fremskridtstanken ikke er konstitutiv for romantikken, dvs. den kan være eller ikke være der, modsat oplysningsfilosofien hvor den hører afgørende med. For det andet er Herders udarbejdelse af folketanken ikke nødvendigvis romantisk eller førromantisk, men den spiller ind i den senere romantik ikke mindst fra Fichtes forelæsninger Reden an die deutsche Nation fra $1808^{38}$.

De to afgørende punkter, hvor det romantiske omsving slår ind i Grundtvigs liv og forfatterskab, er for det første fornuftsopgøret. Hvor endnu Herder (og Kant) i solidaritet med oplysningsprojektet forsøger at korrigere svaghederne ved fornuftsbegrebet, og hvor Herder derfor kan sætte en modificeret fornuft som ideal for og indbegrebet af humanitet, så lader Grundtvig faktisk ethvert begreb om fornuft ude af betragtning ${ }^{39}$ - bortset fra de steder han i opposition til skolastisk eller idealistisk spekulation påberåber sig den sunde menneskeforstand - , og han kunne da slet ikke forestille sig fornuft som et ideal som såvel individ som kultur stræbte at realisere. Jeg skal vende tilbage til dette punkt til sidst.

For det andet er det tydeligt at Grundtvigs bibelopfattelse i forlængelse af romantikkens katolicerende tendens, nemlig der hvor romantikerne søgte tilbage til en europæisk enhedskultur (katolske middelalder), unddrager sig en egentlig konfrontation. Når Grundtvigs bibelsyn i forlængelse af den mageløse opdagelse mange gange uden videre hævdes som liberalt, samtidig med at flere, stærkest Ole Vind i sin disputats, helt modsat hævder det som fundamentalistisk ${ }^{40}$, så antyder det en manglende mellembestemmelse, uagtet Grundtvigs foragt for disse; og denne er netop at finde $i$ en romantisk indflydelse.

Ole Vind har ret $i$ at Grundtvigs bibellæsning virker som et modsvar til en historisk-kritisk distancering, men det er ikke træffende at kalde den fundamentalistisk og bogstavelig ${ }^{41}$. Et for mig at se bedre forslag vil være poetisk biblicisme. For det første indrømmer Grundtvig med en vis Gelassenheit på sine gamle dage at en bibelkritik ikke er ødelæggende. For det andet og væsentligst, selv om Grundtvig i praksis bruger Bibelen som var den åbenbaringen af den evige sandhed, så bruger han den netop 
ikke bogstaveligt. Tværtimod er det ved en udstrakt anvendelse af $» k r e a-$ tiv hermeneutik «; $\mathrm{fx}$ vil ingen fundamentalist acceptere Grundtvigs syner i den poetiske læsning af Apokalypsens menighedsbreve, som den udfoldes i Christenhedens Syvstjerne.

Hvis min bestemmelse har nogen rimelighed, forklares den samtidig i lyset fra romantikkens optagethed af poetisk inspiration: Den beåndede læsning åbner akkurat de dunkelheder som den også er så optaget af, ja netop i dunkelhederne, i anelsen og det ikke klart udtalte, skjuler sig afgørende hemmeligheder, hemmeligheder som skal åbenbares så at sige poetisk. Grundtvigs høje tanker om skjalden og profeten kan vel kun forstås ud fra et romantisk perspektiv, nemlig som en modificeret pendant til geniet. $\mathrm{Og}$ ikke mindst, romantikkens efterhånden anstrengte forhold til fornuften forklarer næsten bedre den gamle Grundtvigs nonchalance over for skriftkritik end hans ung- og manddoms voldsomme modstand. Dobbeltheden i udtrykket poetisk biblicisme forklarer også hvorfor man i kraft af den poetiske bibellæsning på én gang kan finde Grundtvigs bibelbrug både indsigtsgivende og inciterende, og den forklarer i kraft af det biblicistiske drag hvorfor man kan opfatte den som fundamentalistisk, og hvorfor den kan virke så irriterende i sin ikke kun tilsyneladende skråsikkerhed.

\section{Teologiske tab}

Oplysningstiden satte sine markante, ja voldsomme og tildels destruktive, præg på kristendommen. Ofte foregik det sådan at man hentede kristne forestillinger ind for fornuftens domstol og dømte alt dermed uoverensstemmende som overtro og værdigt til udstødning og forglemmelse. Herders storhed består bl.a. i at se at oplysningsfilosofiens fornuftsbegreb ikke tilfældigt stod i fare for at slå om i irrationalitet.

Formatet i Herders projekt ligger i den klare erkendelse af at en kritik af oplysningsprojektet må foregå i solidaritet med dets anliggende, og dette bestemmer han med rette som et frigørelses- subsidiært frihedsprojekt. Herder fastholder at friheden må balanceres eller underkastes en binding til et mål om humanitet, hvis ikke den skal antage totalitære, utopiske og destruktive træk - og både den franske revolution og det 20. århundrede har til overmål bekræftet indsigten. Og altafgørende: Humaniteten kan kun bevare sin karakter af fornuft under den forudsætning at den er religiøst bundet; kun kristendommen, herdersk: Jesu religion, kan 
sikre fornuft og frihed ved at gøre tro og tillid til fundament. Fornuft og humanitet er altså nok en kritisk mulighed i forhold til åbenbaringen, men kun fordi de selv lever af åbenbarede idealer. Uden åbenbaring ingen fornuftig sammenhæng.

Set i det lys kan man for det første se at Herder faktisk lod oplysningens berettigede kritik af kristendommens, subsidiært: de kristnes, magtkrav stå ved magt; faktisk så han med rette at friheds- og oplysningkravet var et kristent hjerteanliggende, og derfor måtte såvel Skrift som dogme selvsagt være underkastet historisk kritik. Med andre ord: Ikke bare historiske epokers egenret hævdes, så historien gøres til en del af menneskets humane dannelse (både formalt og materielt), men kristendommen selv udscettes for en historisering, også Skriften, dogmerne, ja åbenbaringen, giver kun mening forstået under de givne historiske betingelser, og kan derfor kun hævdes træffende og sanddru under hensyntagen til nye betingelser. Ydermere, for det andet og nok så væsentligt: Herder var klar over at den mere eller mindre åbne ateisme, inkl. de ateistiske træk i deismen, samt nyhedenskabet (ofte i klassicistisk forklædning) indebar at ikke alene skulle kristendommen selv historiseres, men tillige havde den mistet forklaringskraft. De kristne grundsandheder forklarede ikke længere verden og ethvert menneskes liv, de skulle selv forklares.

Grundtvig undsiger på afgørende punkter en sådan historisering. Sandsynligvis pga. det romantiske omsving. Jeg kan ikke se andet end at den franske revolutions udartning, støttet af reaktionen på Napoleon, navnlig i de tyske lande, har skabt et klima, hvor romantiske betingelser på nærmest selvindlysende måde lod oplysningsprojektet i stikken ${ }^{42}$. I al fald falder det aldrig Grundtvig ind, at fornuften kunne have en positiv frigørende funktion, ja måske udgør et nødvendigt humant karakteristikon, som det eneste sted ubeføjede magtkrav, illusioner, fordomme og lignende kan afsløres.

I forlængelse af sin poetiske biblicisme undgår Grundtvig da også enhver problematisering af åbenbaringsbegrebet, tværtimod kan den stadig mere bastante hævdelse af den kirkelige anskuelse kun ses som den immuniseringsstrategi, som skal lade en tvivlsom åbenbaringstro uantastet. Hvor Herder så både natur og historie som virkninger eller elementer i Guds åbenbaring, trak Grundtvig sig reelt tilbage i en historieskrivning som i sin frelseshistoriske konception mere minder om en præmoderne krønikeskrivning end om oplysningstidens, endsige Herders, historiefilosofi. Mest bemærkelsesværdig er det vel i den forbin- 
delse, at den manglende udfordring fra andre tiders selvforståelse sætter sig som et konstituerende træk i Grundtvigs historieskrivning. Den tendens til ørneblik på historien som oftest unddrager sig konkrete menneskers tanker og forhåbninger, idealer og handlingsmotiver, skyldes vel netop at Grundtvig udviser en påfaldende mangel på reel udfordring fra det anderledes i historien, fra alt det som kunne have problematiseret den frelseshistoriske konception ${ }^{43}$.

Det $\mathrm{i}$ og for sig afgørende tab som den manglende historisering af kristendommen indebærer, og den deraf manglende forståelse for kristendommens påtrængende behov for en nyformulering som både fastholder uopgivelige grundpositioner og imødekommer behovet for at mennesket selv forklares af kristendommen ${ }^{44}$, det tab står ikke alene. Dertil føjer sig et andet tab, som skyldes fornuftsbegrebets marginalisering eller direkte forhånelse: enhver fornuft identificeres med gold rationalisme, en position som allerede på Grundtvigs tid havde karakter af beslutsom karikatur ${ }^{45}$.

Kun ved at trække sig tilbage til sin »fæstning «, den kirkelig anskuelse med samt sin særlige, produktive biblicisme, kan Grundtvig illudere at kristendommen er intakt og ikke har metafysiske spørgsmål behov. Metafysikken kom ganske vist selv under angreb, men metafysiske spørgsmål som totalitet (dvs. altings sammenhæng), enhed og menneskets bestemmelse har siden teologiens fødsel været væsentlige træk, så teologien ikke bare trak sig tilbage til en åbenbaringspositivistisk fæstning, men var i samtale med ikke-kristne og/eller filosofiske erkendelser, som var alment tilgængelige. Det betyder at når fx syndefaldets karakter af historieskrivning definitivt må opgives, kan man stadig fx med Herder - eller Kierkegaard i Begrebet Angest - filosofisk argumentere for menneskets tidslige splittelser, hvorimod Grundtvig meget svagere enten hævder syndefaldet som et faktum eller på romantisk vis spørger til forskellige former for fænomener af verdslig karakter, som kan åbne for Gudstanken ${ }^{46}$.

Men meget mere påtrængende er tabet, når der spørges til den specifikke åbenbarings quaestio juris: Med hvilken ret hævdes akkurat den kristne åbenbaring som sand, og ikke fx Allahs i Koranen? Når åbenbaringsbegrebet bindes til Bibelen, uanset Grundtvigs skabelsesteologiske folketanke og medfølgende folkeånder, og fornuften/filosofien udgrænses ${ }^{47}$, hvordan argumenterer man så for at Bibelens åbenbaringskrav ikke er tilfældigt, traditionsbetinget? Det er meget vel en væsentlig indsigt at den direkte vej fra filosofi til dogmatik er brudt, men er en 
kobling af den grund overflødig? Hvordan undgås med andre ord den vilkårligste decisionisme? Og hvordan undgår Grundtvigs teologi, at netop kristendommens sandhedskrav stik imod intentionen slår om i postulat, er tilfældigt eller bortfalder,hvis det ikke er i dialog med andres sandhedsprætentioner?

Måske er de romantiske træk i Grundtvigs teologi af mere omfattende og skæbnesvanger karakter, end det umiddelbart kommer frem. Netop sammenlignet med Herder - som i sin markante historisering også af kristendommen og $\mathrm{i}$ sit forsøg på at udarbejde en metafysik under inspiration fra spinozismedebatten er på højde med problemstilingen ${ }^{48}-$ tager Grundtvigs tilløb til teologi sig ud som det modsatte af dens selvfremstilling: Nemlig som afgørende indrømmelse til modernitetens kritik, hvilket gør en aktuel systematisk teologisk tilknytning ufrugtbar ${ }^{49}$.

Vil man herimod hævde, at Grundtvigs salmer i deres suveræne på én gang originalitet og klassisk kristne form frembyder det væsentligste, må det siges at salmer netop på grund af deres karakter af klage- og lovsang ikke kan tilbyde løsningen på de påtrængende spørgsmål om en basal redegørelse for $\mathrm{fx}$ åbenbarings- $\mathrm{og}$ fornuftsforståelsen. En altomfattende begrundelsessammenhæng (i.e. metafysik) er ikke kun vigtig på grund af 1800-tallets religionskritik, som jo faktisk begynder i Grundtvigs levetid med Feuerbach, men den har sin permanente nødvendighed, fordi kristendommens sandhedskrav appellerer til fornuften, og kun ved at tage denne appel alvorligt kan en ansvarlig teologi indfri kravet om ikke at udlevere sig til illusioner, fordomme, selvbedrag m.m.

Ligeledes må jeg anføre, at den forestilling at menneskelivet er en gåde, som vist særligt i højskolekredse har nydt stor yndest, ikke er et tilknytningspunkt for en almenmenneskelig betragtning, da den henter sin tilsyneladende evidens fra en skabelsesteologisk konception, hvor den teologiske tilknytning er forudsat i kraft af gudbilledligheden; menneskets gåde er altså ikke kun metafysik ${ }^{50}$. Hos Augustin bliver det at han er blevet sig selv et spørgsmål først et faktum, da han ser sig selv i Guds lys ${ }^{51}$, og da menneskets gåde overhovedet først bliver til i lyset af Guds åbenbaring, kan den ikke samtidig hævdes som en forudsætning for at tale om Guds åbenbaring. Når den freudske psykoanalyse antageligt bakker op om menneskets gådefuldhed, er det næppe holdbart; eller mere præcist: det tager sig kun sådan ud, fordi psykoanalysen i Freuds udgave inkonsistent og ubegrundet, om end sympatisk, fastholder menneskets ansvarlighed. Gåden hos Augustin beror netop på at ondskab og godhed er mennesket qua menneske tilhørende, og ikke manikæisk kan spaltes 
således at mennesket reelt ikke har lod og del i det onde; det kommer andetsteds fra (ligesom psykoanalysen ofte stik modsat Freuds intention har tjent som undskyldning). Gådefuldheden består i, at netop i lyset fra og som en integreret del af den ene Guds skaberværk åbenbares et uforståeligt misforhold mellem faktisk væren og forudgivet bestemmelse.

\section{Grundtvig som oplysningstoenker}

På trods af ovenstående er det dog indlysende, at Grundtvig også på sin måde var oplysningsmand. Ikke alene kan højskolen ikke tænkes uden, men uagtet forskellen på metafysik og teologi, så var Grundtvigs antropologi grundlæggende baseret på menneskets gådefuldhed $o g$ dets gang mod oplysning, opklaring, ja forklarelse. Dette mål er også i fin forlængelse af Herders tænkning, men romantikkens mellemkomst kan foranledige en nærmere præcisering; for det lader sig næppe begribe at romantikken ikke skulle farve oplysningsidealet.

$O g$ det gjorde den da også. Skiftet fra Herders humanitets- og fornuftsideal, uagtet religiøs forankring, til Grundtvigs også historiske, men mere markant bibelske oplysningstanke, er da også romantisk begrundet, og det er netop synligt i fornuftsidealets fravær.

For at karakterisere Grundtvigs oplysningstænkning vil jeg foreslå at forstå den som en af romantikken sprogligt opladet oplysning, eller måske bedre: En kristelig oplysningstænkning som er gået igennem den romantiske erfaring, en kristeligt beriget transsubstantiation af romantikken $^{52}$.

\section{Noter}

1. Jf. Jakob L. Balling, "Grundtvig, Dante, Milton, and the Problem of European Continuity« i Heritage and Prophecy. Grundtvig and the English-speaking World, ed. by A.M. Allchin, D. Jasper, J.H. Schjørring, and K. Stevenson, Aarhus University Press 1993, s. 73-86.

2. Det moderne aspekt undgår selvfølgelig ikke Balling, jf. ibid. s. 83 f., hvor fraværet af dén kosmiske orden, som hos Dante og Milton er overordentlig betydningsfuld, tolkes som af »prime significance for assessing the »modernity poem «.

3. C.I. Scharling, Grundtvig og Romantiken belyst ved Grundtvigs forhold til Schelling, Gyldendal 1947. William Michelsen har et langt og fint afsnit om Herder i disputatsen Tilblivelsen af Grundtvigs Historiesyn, Gyldendal 1954, s. 
311-48; Helge Grell inddrager ham i sin disputats Skaberånd og folkeånd. En undersøgelse af Grundtvigs tanker om folk og folkelighed og deres forhold til hans kristendomssyn, Anis 1988, s. 21-45; og senest har Ole Vind, også i en disputats, gjort Herder til afgørende omdrejningspunkt - og helt, Grundtvigs historiefilosofi. Gyldendal 1999, passim.

4. Herder udsendte i 1799 Verstand und Erfahrung. Eine Metakritik zur Kritik der reinen Vernunft og i 1800 Kalligone. Vom Angenehmen und Schönen, som begge var bitre opgør med Kants filosofi.

5. Denne lille bog har sandsynligvis via Vilhelm Grønbechs forfatterskab haft en betydelig indflydelse herhjemme; i Grundtvig-forskningen via Grønbech til Kaj Thaning. Dansk med forord af William Michelsen Om samspillet mellem erkendelse og folelse i menneskets sjoel 1955.

6. Således Herder-kenderen Günter Arnold, "Situationen und Annäherungen Probleme einer aktuellen Herder-Biographie« i Martin Bollacher, Hrsg., Johann Gottfried Herder, Geschichte und Kultur, Königshausen \& Neumann, Würzburg 1994, s. 403-414.

7. Kirkens Gienmaele, i N.F.S. Grundtvig, Udvalgte Skrifter 4, red. Holger Begtrup, Kbh. 1906, s. 396-429, citat s. 416. (Herefter US).

8. Når det ikke blev et problem for Luther, skyldes det at Luther fastholdt fælles trosbekendelser med den katolske kirke, og derfor kun anvendte skriften som et kritisk korrektiv vendt mod kirken. Og vigtigt: Skriftens autoritet var generelt forudsat, så Luther kunne nøjes med at påberåbe sig skriften tilstrækkelige klarhed. Pointen var ikke at skriften var ufejlbarlig - hvilket netop ingen bestred! men at ingen kunne tilrane sig magten til tolkning og udlægning ved at hævde Bibelens uklarhed og en anden, menneskelig, instans' deraf følgende nødvendige klargøring, jf. fx Martin Luther, Assertio omnium articulorum (1521), Weimar Ausgabe VII, $96 \mathrm{ff}$, dansk i Teologiske tekster, red. af Afdeling for Dogmatik, Aarhus Universitet, 1989 eller senere, s. 158-168.

9. Dr. H. Martensen, Til Forsvar mod den saakaldte Grundtvigianisme, Kbh. 1863, s. 7 ff. Martensen har også som den mig bekendt forste påpeget svaghederne og implikationerne i Grundtvigs »opdagelse«, jf. også præcist Edv. Lehmann, Grundtvig, Kbh. s. 157-79; se også Kaj Baagø, „Grundtvigs mageløse opdagelse. Et bidrag til dens tilblivelseshistorie« i Grundtvig-Studier 1957, s. 37-50.

10. Med forbehold, for nok kunne andre pege på de fælleskirkelige trosbekendelser, men ingen andre end Grundtvig gik så vidt at udskifte Bibelen som kirke- og trosgrund med den apostolske trosbekendelse, ved helt urimeligt at hævde dens oprindelse af »Herrens egen Mund« - i sandhed mageløst. Dette sker dog først i de efterfølgende år.

11. Ikke kun i sine Christliche Schriften, men nok så tydeligt, uden her at forudgribe Grundtvigs brug, i Ideen, hvor bekendelsesformlen ved dåben udtrykkeligt går forud for skriftens kanonisering, se Ideen zur Philosophie der Geschichte der Menschheit, bog IV, 17, 1, i Herder Werke, Deutscher Klassiker Verlag, Frankfurt am Main, bd 6, 1989, Hrsg. Martin Bollacher, s. 715 ff.

12. Mindedigtet over Reinhard findes bl.a. i US 3, s. 98-103, med kommentar s. 104 ff. Bemærkelsesværdigt henviser Leif Grane til digtet uden videre forespørgsel til Reinhards betydning,jf. »Grundtvigs forhold til Luther og den lutherske tradition« 
i Grundtvig-Studier 1998, s. 21-41, henvisning s. 24 med note s. 37.

13. Reinhard gik så vidt at han i år 1800 tog Konkordiebogen med på prædikestolen, jf. Emanuel Hirsch, Geschichte der neueren evangelischen Theologie, bd. 5, 1954, s. 81 .

14. Jf. også Grundtvig, Verdens-Krøniken fra 1817, i US, bd. 3, s. 706 f.

15. Jf. Kirkens Gienmoele, US 4, s. 413; Om den sande Christendom, ibid., s. 479, 487 ff.; og fx Den christelige Børnelardom, US 9, s. 338 ff.; eller med reference til Kirkens Gienmæle: »Det er nu hele tredive Aar siden, det Lys gik op for mig, at det hverken er eller kan være nogen som helst Skrift, hellig eller søgn, men ene og alene »Troens Ord i vor Mund«, den mundtlige, lydelige, offentlige TrosBekjendelse ved Daaben efter Vorherres Jesu Kristi egen Indstiftelse, som udtrykker, og har lige fra Begyndelsen udtrykt, og skal til Verdens Ende udtrykke, den uforanderlige, for alle Kristne fælles kristne Tro, hvorpaa vi døbes i Faderens og Sønnens og den Helligaands Navn«, ibid., s. 357. Derfor er jeg, bemærket en passant, helt enig når Erik Kelstrup imod Henning Høirup gør gældende, at den kirkelige anskuelse, og ikke modsigelsens grundsætning, har karakter af „teologisk aksiom « i Kirkens Gienmoele, jf. Kelstrup, »Grundtvigs anvendelse af modsigelsens grundsætning i "Kirkens Gienmæle» - filosofisk belyst « i GrundtvigStudier 2000, s. 126-53. Kun skal jeg bemærke at Leibniz' mening med modsigelsens grundsætning intenderede at muliggøre en bevisførelse, og som sådan kom den logisk før selve beviset, jf. Dieter Henrich, Der ontologische Gottesbeweis, J.C.B. Mohr (Paul Siebeck) Tübingen 1960, s. 45 ff. Når Grundtvig i sig selv giver modsigelsens grundsætning bevisførende kraft er det logisk illegitimt, og fejlen ligger i at almengøre sætningen uden for problemet om det ontologiske gudsbevis. Dvs. ud over Tugendhats skelnen mellem sproglig og ontologisk kan man tilføje Aristoteles' skelnen mellem kontrære og kontradiktoriske modsætninger.

16. Også Schleiermacher, som Grundtvig selvfølgelig kendte til, arbejdede på selvfølgeligste måde i forlængelse af den problemstilling som var Grundtvigs, om end med anderledes præmisser og langt mere omfattende begrundelsessammenhænge. I Der christliche Glaube (1. udg. 1821-22) stadfæstes det som en selvfølge, at troen var før Skriften, og alligevel hævdes i modificeret form skriftens autoritet, jf. $\S 127 \mathrm{ff}$. Schleiermachers fortsatte styrke og uomgængelighed i den henseende ligger bl.a. i en præcisering af såvel åbenbaringsforståelsen som Skriftens position.

17. Udtrykkene er Kaj Thanings i Menneske først - Grundtvigs opgør med sig selv, 1963.

18. Til en kort orientering, se Theologische Real-Encyklopädie, bd. 22, 1991, s. 442444, jf. også Hirsch, op.cit., bd. 5, s. 92 ff.

19. Jf. note 3; henvisningen gælder også Grundtvigs syn på og bedømmelse af Herder, jf. fx Michelsen, Tilblivelsen af Grundtvigs Historiesyn, s. $311 \mathrm{ff}$.; og Vind, Grundtvigs Historiefilosofi, s. $66 \mathrm{f}$.

20. Dette er synspunktet i Auch eine Philosophie der Geschichte zur Bildung der Menschheit.

21. Danne-Virke, I, 1816, s. 120.

22. Ibid., s. 116. 
23. Ibid., s. 117.

24. Men netop at det faktisk er analogitænkning viser hvor lidt Grundtvig ofte gør sig sine forudsætninger og rækkevidden af sine påstande klar: På den ene side virker det som om han er klar over den klassiske værensanalogis (analogia entis) sammenbrud, på den anden side er der en nødvendig sammenhæng; men hvad vil det sige at et billede er historiseret? Og hvordan skal man forstå at det tidslige forløb som billede siger noget om det evige, om ikke det evige selv har tidsligt forløb? Selv om man tænker trinitarisk - som Karl Barth, der dog netop ikke hævder en historisering i triniteten - må en sådan opfattelse skabe flere problemer end den løser.

25. Ibid.

26. Ibid., s. 118. Andetsteds, Danne-Virke, III, 1817, s. 248 siger Grundtvig, at den vidskab der skal forklare mennesket $i$ dets »oversandselige Forhold» forudsætter »nødvendig en Aabenbaring af Forholdet, den være saa blot naturlig: mythisk, eller overnaturlig: theopneustisk, Indbildnings-Kraften er den naturlige Evne til at modtage og forbinde, oversandselige Forestillinger...«. Dette er romantisk tænkning i forlængelse af oplysningsfilosofiens opprioritering af det æstetiske som væsentlig erkendelseskilde, således som det sker hos Baumgarten. Det æstetiske er endnu hos Baumgarten tænkt "græsk «, aisthesis, det sanselige, og denne kategoris erkendelsesmæssige placering hos Baumgarten danner en vigtig forudsætning til forståelse af Herders tænkning, jf. Hans Adler, Die Prägnanz des Dunklen. Gnoseologie - Ästhtetik - Geschichtsphilosophie bei J.G. Herder, Felix Meiner, Hamburg 1990, især s. 26-48. Og altså også til forståelse af Grundtvigs forudsætninger.

27. Haandbog $i$ Verdens-Historien, Tredie Deel, 1843, US 7, s. 505.

28. Haandbog, Anden Deel, 1836, US 6, s. 548.

29. Op. cit., US. 7, s. 222 (spatiering ophævet).

30. Ibid., s. 392.

31. Til motivet $\mathrm{i}$ anden sammenhæng, Jens Holger Schjørring, „Om Fugl Fønixmotivet. Til belysning af forholdet mellem poesi og kirkelære« i Ordet, kirken og kulturen. Afhandlinger om kristendomshistorie tilegnet Jakob Balling. Red. C. Bach-Nielsen m.fl., Aarhus Universitetsforlag 1993, s. 379-97.

32. Jf. den mange gange fremhævede fortale til Nyaars-Morgen, i US 4, s. 246.

33. Jeg antager at der er indre sammenhæng mellem denne sammenknytning og erkendelsen af Danne-Virke-forsøgene som blindgyde. Fornuft-begrebet og selvbevidstheden som tilknytning til og »bevis« for Gud, falder jo bort efter DV.

34. Holdt som tale; trykt i Herder, Werke, Deutscher Klassiker Verlag, Frankfurt am Main 1998, bd. 8, s. 203-219. Udgiveren Hans Dietrich Irmscher sammenfatter præcist således: „Gegenstand der Rede ist nicht, wie der Titel nahelegen könnte, die Frage der Unsterblichkeit der Person, sondern das Prinzip der Geschichtlichkeit, die Entstehung eines Zusammenhangs unter den disparaten geschichtlichen Phänomenen.« ibid., s. 1039.

35. Jf. A. Pontoppidan Thyssen, »Menneske først - . Om Kaj Thanings Grundtvigdisputats« i Kirkehistoriske Samlinger 7. rk. V 1963-65, s. 554-601; Bent Christensen, „Var Grundtvigs nyerkendelse i 1832 en tragisk hændelse?« i GrundtvigStudier 1989-1990, s. 16-31. 
36. Se artiklen »Digteren og Den Sandheds Ånd. Grundtvigs helligåndsteologi og den engelske romantik« i Grundtvig-Studier 1991, s. 68-85.

37. Eksemplet er for egen regning, men se Jørgen I. Jensen, »Grundtvig og nutidens problemer med historien« i Københavns Universitets Almanak 1984, s. 119-27.

38. En nøjere redegørelse for forskelle og ligheder mellem folke-opfattelsen hos Herder og Grundtvig vil kræve en del plads, da Grundtvig efterhånden udvikler sine tanker gennem forfatterskabet; betænk blot at han i 1834 kun tilskrev folket rådgivende status, dvs. ingen folkesuverænitet. Til en første orientering om Herder, se Isaiah Berlin, Three Critics of the Enlightenment, Princeton UP, 2000, s. 168-242 (tidligere trykt bl.a. i Vico and Herder, 1976); om Grundtvig, se A. Pontoppidan Thyssen i Grundtvig og grundtvigianismen i nyt lys, red Christian Thodberg og Anders Pontoppidan Thyssen, Anis 1983, s. 84-114, 225-86, 335-59; og Grells i n. 3 nævnte disputats.

39. Med forbehold for de tidligere nævnte uklare spekulationer i DV. Paradoksalt nok, har de vel deres inspiration fra rationalisten Wolff, medieret gennem universitetets filosofiprofessor Børge Riisbrigh. I DV arbejdes også ansatsvis med et begreb om »historisk fornuft«, men heller ikke det står sin prøve i det senere forfatterskab.

40. Se Vind, op.cit., s. 208 og passim.

41. Ibid.

42. De katolicerende træk i Grundtvigs tænkning var jo en del af den romantiske strømning; bemærk dertil de mange konversioner fra protestantisk hold til den katolske kirke (prominente navne som Graf Stolberg i 1800 og Friedrich Schlegel i 1809), som netop begrundedes med den franske revolution som en logisk folge af reformationen, jf. art. "Konvertiten" i Religion in Geschichte und Gegenwart, 1959, 3. udg., bd. 3. Måske skal jeg minde om at den franske revolution allerede begyndte at kamme over i diktatur, da man i 1790 forlangte at alle katolske præster skulle sværge revolutionen en loyalitetsed, den såkaldte civilkonstitution.

43. De mange lange passager af trivielle eller tvivlsomme udredninger brydes dog stedse af udbrud af nærmest genialt klarsyn; se $\mathrm{fx}$ de indsigtsgivende, om end fordømmende, sider om jesuitterne i Haandbog $i$ Verdens-Historie, Tredie Deel, US 7, s. 637 ff. - For en lignende kritik af Grundtvigs kirkehistorieskrivning, se Jakob Balling, »Bispestav, skolemesterpen - og menighed. Den ældre Grundtvig som kirkehistoriker « i Kirken aflevende stene. Den grundtvigske tradition i dansk kirkehistorieskrivning, red. af Carsten Bach-Nielsen og Per Ingesman, Anis 1994, s. 45-59, særlig s. $57 \mathrm{f}$.

44. Dette skal forstås rigtigt: Under forudsætning af at have accepteret det gammeleuropæiske udgangspunkt er der i Grundtvigs skrifter righoldige muligheder for lade sig oplyse; men under den forudsætning er der meget at hente i ethvert stort forfatterskab, også uden for det gammeleuropæiske, både i islam, buddhisme og ateisme.

45. Er det ikke indlysende at Grundtvigs karikatur af rationalitet går fint i spænd med nutidige positioner i den såkaldte postmodernisme, som også lever af at gøre op med selvproducerede karikaturer, og at Grundtvig næsten gnidningsfrit kan anvendes i det øjemed? 
46. Positivt betyder det sidste til gengæld, at enhver pukken på arvesynd bliver ganske vanskelig.

47. Grundtvigs folkeånder erstatter på tvetydig måde den gamle tanke om en almen åbenbaring, dvs. den naturlige teologi. Denne var fra begyndelsen tænkt med tilknytning til Romerbrevet 1, 19-21 og var altså bundet til fornuften. Grundtvigs tanke om folkeånder kan ikke gøre det ud for en afløser, men har nærmest karakter af en pluralitet af residual- eller sekundæråbenbaringer; disse er nemlig $i k k e-\mathrm{i}$ fornuftsbegrebets fravær - strengt almenmenneskelige. De bestemmes i 1827 vagt således: »... en dunkel, aandelig Følelse af en Eenhed i Mangfoldigheden, til Trøst, til Ære og Fryd for hver Medlem af Samfundet, der har Sind til godvillig at dele Byrden, og i Nødsfald, at glemme sin Enkelthed over Sammenhængen med det Hele... har skabt ethvert Folke-Liv ...«, Grundtvigs literaire Testamente, US 5, s. 171. Altså en dunkel følelse skaber folkelivet; dét er romantisk, og en sådan følelse kan ikke bære det som den tilskrives. Grundtvigs udvikling fører ham måske nok fra det romantiske træk heri, men ikke nærmere en almen åbenbaring; jf. fx »Folkelighed og Christendom « (1848), hvor der siges at »fordi Aands-Frihed og Folkelighed er hvad Christendommen, for at virke i sin Aand, maa enten forefinde eller, hvis de fattes, skabe dem«, US 9, s. 85.

48. I dialogerne Gott. Einige Gespräche. 1787 i Herder, Werke, bd. 4, Frankfurt am Main 1994, s. 679-794,

49. Set $i$ dette perspektiv er der en lige linje fra Grundtvig til Barth og barthianismen - betænk hvordan Regin Prenter knytter til ved Grundtvig - på den ene side, og Tidehverv på den anden; begge steder lod uden videre metafysikken falde, ja hilste i forlængelsen af religionskritikken dens fald velkommen som en befrielse. Det forekommer mig en tvivlsom gevinst, og jeg kan derfor ikke tilslutte mig Peter Thyssen, som kun ser chancen, jf. „Grundtvig og Guds Ord-teologien» i Teologi og modernitet, red. Peter Thyssen og Anders Moe Rasmussen, Aarhus Universitetsforlag 1997, s. 66-79.

50. Jf. Nordens Mythologi 1832, US 4, s. 400 f. og 408. Det fremgår tydeligt at Grundtvig også argumenterer teologisk, jf. s. 400 f.

51. Eller med Guds øjne, blik: »in cuius oculis mihi quaestio factus sum «-i hvis øjne jeg er blevet et spørgsmål for mig selv, Confessiones $\mathbf{x}, 33$. Forskellen mellem Augustin og Grundtvig er på dette punkt også manifest: Grundtvig ser det som et positivt udgangspunkt, for Augustin var det en sygdom, for sætningen fortsætter »et ipse est languor meus«.

52. Det forekommer mig derfor at være en kortslutning i, ja en grundskavank ved Ole Vinds disputats, at Grundtvig partout skal føres tilbage til en Herder-inspiration, op.cit., s. 148 ff. og passim, ja "Grundtvig er den største danske oplysningstænker«, s. 15. Baggrunden herfor er dels at Ole Vind overtager den senere romantiks og den moderne religionskritiks karikatur af Kant og fornuftsbegrebet iøvrigt; dels at Ole Vind alligevel i sin fascination af Grundtvigs åndsbegreb gerne vil videreføre en ajourført åndstænkning. Imidlertid hænger Ole Vinds åndsbegreb i luften, da hans manifeste historicisme $i k k e$ formår at lade ånden have mennesket, det er mennesket der skal have ånden, jf. s. 558 ff. Det er bemærkelsesværdigt at Vinds disputats, der henter meget af sin overbevisningskraft akkurat ved at fastholde en sammenhæng mellem kristendom og historie, ender med besværgende 
at postulere at »For Grundtvig var ånden imidlertid hverken transcendent eller metafysisk, men et udtryk for menneskets sande væsen«, s. 560. Det forekommer mig i så fald at være en definition af transcendens. Desuden er ånd meget bekvemt afkoblet fra enhver konnotation med Helligånd, dvs. sandheds og kærligheds Ånd. 